\title{
BMJ Open The Scottish school leavers cohort: linkage of education data to routinely collected records for mortality, hospital discharge and offspring birth characteristics
}

\author{
Catherine H Stewart, Ruth Dundas, Alastair H Leyland
}

To cite: Stewart $\mathrm{CH}$, Dundas $\mathrm{R}$, Leyland AH. The Scottish school leavers cohort: linkage of education data to routinely collected records for mortality, hospital discharge and offspring birth characteristics. BMJ Open 2017;7:e015027. doi:10.1136/ bmjopen-2016-015027

- Prepublication history and additional material is available. To view please visit the journal (http://dx.doi.org/10.1136/ bmjopen-2016-015027).

Received 3 November 2016 Revised 10 February 2017 Accepted 23 March 2017

CrossMark

MRC/CSO Social and Public Health Sciences Unit, University of Glasgow, Glasgow, UK

Correspondence to Dr Catherine H Stewart; catherine.stewart@glasgow. ac.uk

\section{ABSTRACT}

Purpose The Scottish school leavers cohort provides population-wide prospective follow-up of local authority secondary school leavers in Scotland through linkage of comprehensive education data with hospital and mortality records. It considers educational attainment as a proxy for socioeconomic position in young adulthood and enables the study of associations and causal relationships between educational attainment and health outcomes in young adulthood.

Participants Education data for 284621 individuals who left a local authority secondary school during 2006/2007-2010/2011 were linked with birth, death and hospital records, including general/acute and mental health inpatient and day case records. Individuals were followed up from date of school leaving until September 2012. Age range during follow-up was 15 years to 24 years.

Findings to date Education data included all formal school qualifications attained by date of school leaving; sociodemographic information; indicators of student needs, educational or non-educational support received and special school unit attendance; attendance, absence and exclusions over time and school leaver destination. Area-based measures of school and home deprivation were provided. Health data included dates of admission/discharge from hospital; principal/secondary diagnoses; maternal-related, birth-related and babyrelated variables and, where relevant, date and cause of death. This paper presents crude rates for all-cause and cause-specific deaths and general/acute and psychiatric hospital admissions as well as birth outcomes for children of female cohort members.

Future plans This study is the first in Scotland to link education and health data for the population of local authority secondary school leavers and provides access to a large, representative cohort with the ability to study rare health outcomes. There is the potential to study health outcomes over the life course through linkage with future hospital and death records for cohort members. The cohort may also be expanded by adding data from future school leavers. There is scope for linkage to the Prescribing Information System and the Scottish Primary Care Information Resource.
Strengths and limitations of this study

- The Scottish school leavers cohort provides prospective follow-up of school leavers in Scotland for studying associations and causal relationships between educational attainment and health in young adulthood.

- This resource provides access to a large, representative cohort with the ability to study rare health outcomes, such as suicide.

- The cohort is only representative of local authority school leavers and does not include individuals that attended privately funded schools. Although this proportion is low, pupil numbers are not evenly distributed across Scotland, with numbers of private school pupils accounting for a greater proportion of all pupils in some local authority areas than others.

- There may be misestimation of migrants: overestimation for unknown international migrants who are still assumed to be present in the cohort; and underestimation for individuals who have been incorrectly assumed to have migrated to elsewhere in the UK and have been removed from the cohort.

\section{INTRODUCTION}

The WHO recognises that reducing health inequalities among countries and among groups within countries is pivotal in achieving the aim of 'health for all in the $21^{\text {st }}$ century'. ${ }^{1-3}$ To effectively monitor the extent of inequality, they advise that vital statistics from all socioeconomic strata are required. ${ }^{4}$ Socioeconomic factors are known to contribute to inequalities, with those of lower socioeconomic position (SEP) more likely to suffer adverse health outcomes. ${ }^{5-9}$ Commonly used measures of SEP in adulthood include occupational social class ${ }^{9-11}$ and income. ${ }^{9} 10$ However, such measures may not be appropriate for adolescents or young adults. ${ }^{12-15}$ Education is potentially a 
better measure of SEP in young people. It avoids problems associated with occupational social class or income as education level may be determined for everyone. ${ }^{16} 17$ Education can determine future employment opportunities and income and is more likely to remain stable over a person's lifetime and be less sensitive to changes in health status during adulthood than other measures of SEP. ${ }^{18}$ Furthermore, education allows for greater international comparability of SEP. ${ }^{18}$

There is a positive association between education and health, ${ }^{19}{ }^{20}$ with the better educated experiencing more favourable health outcomes such as better self-reported health, lower levels of morbidity and disability, and longer life expectancy. ${ }^{19}{ }^{20}$ Increased education generally also leads to decreased participation in unhealthy behaviours such as smoking and excess alcohol consumption and increased participation in healthy behaviours such as physical exercise and receiving preventative medical care, all of which can protect health. ${ }^{19}{ }^{20}$ Education has also been identified as an important factor underlying inequalities in health. ${ }^{21}$

Linkage of education and health data allows for the role of educational attainment on a range of health outcomes in young adulthood to be studied. Problems with representativeness and power for studying rarer outcomes, such as suicide, can be avoided by using population data. Population data provide the most representative view and greatest number of events for common causes of hospitalisation and death in young adulthood and allow for long-term follow-up. Linking education data with hospital and death records for the population of Scottish school leavers allows access to a large representative cohort for investigating education, a proxy for SEP, as a contributory factor to inequalities in health in young adulthood as well as the early years by looking at offspring birth weight. This will help determine whether intervening at school and targeting underachievers would potentially improve the health of young people and their children and thus contribute to a reduction in health inequalities.

This paper describes the data sources used to create the Scottish school leavers cohort and aims to highlight the potential of this linked data resource for investigating socioeconomic differences in the health of young adults. Initial findings for cause-specific morbidity and mortality by educational attainment are presented in the form of crude rates.

\section{COHORT DESCRIPTION \\ Inclusion criteria}

The cohort was formed by identifying individuals leaving all local authority mainstream secondary and special schools in Scotland during the period 2006/2007 to 2010/2011 from the School Leavers Survey. ${ }^{22}{ }^{23}$ The School Leavers Survey seeks to obtain accurate data on pupils in each school year who leave school having reached the minimum school leaving age or who have exceptional permission to leave school before the minimum leaving age. Pupils in Scotland can leave school in May if they turn 16 years old between March and September or in December if they turn 16 years old between October and February. ${ }^{24}$ The data are held by the Scottish Exchange of Education Data (ScotXed) unit within the Education Analytical Services Division of the Learning and Justice Directorate of the

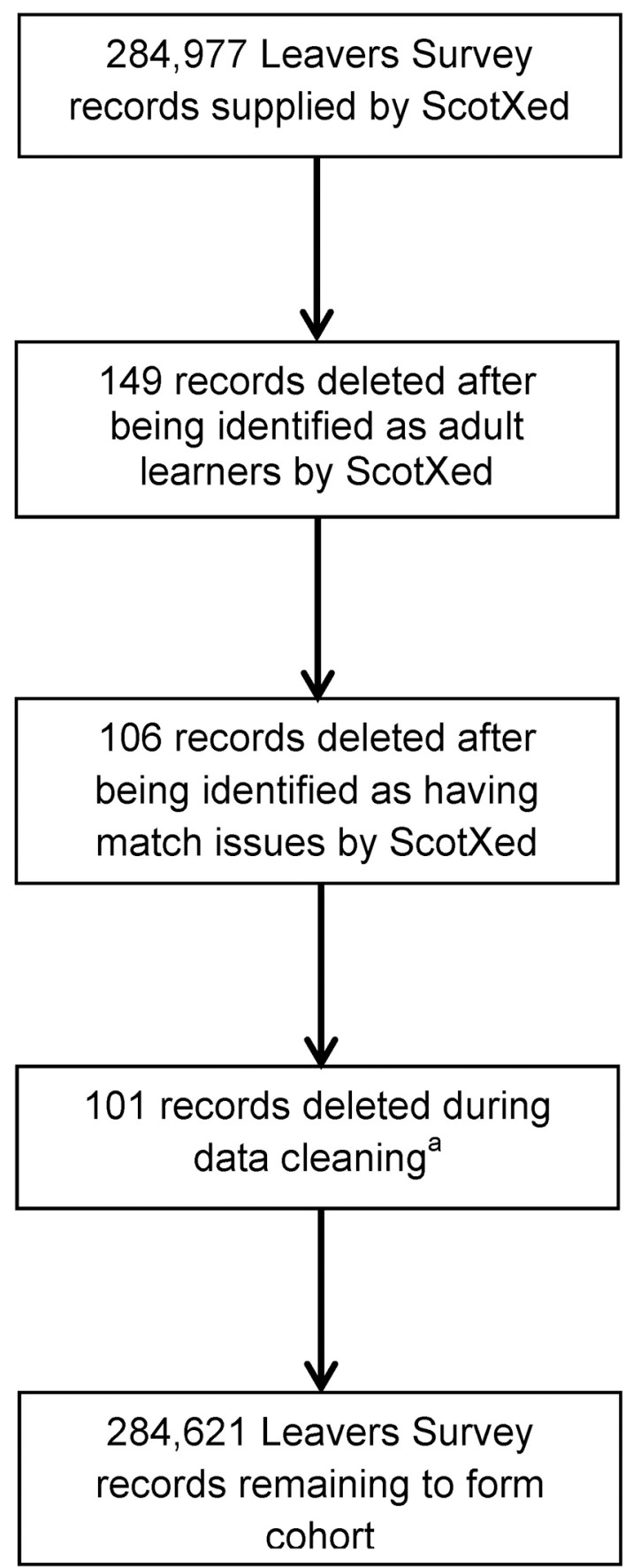

Figure 1 Flow chart of exclusions to form the final cohort.

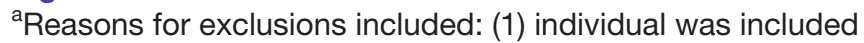
in the School Leavers Survey, but died prior to the date of leaving recorded in the survey. Possible delays in updating school records; (2) possible false links between education and health records. ScotXed, Scottish Exchange of Education Data. 
Table 1 Sociodemographic characteristics of school leavers with Destination Survey record and SMR02 maternity record

\begin{tabular}{|c|c|c|c|}
\hline & Total & $\begin{array}{l}\text { Destination record present } \\
\text { n (\%) }\end{array}$ & $\begin{array}{l}\text { SMR02 record } \\
\text { present } \mathrm{n}(\%)\end{array}$ \\
\hline Male† & 144047 & $133792(92.9)$ & $127892(88.8)$ \\
\hline \multicolumn{4}{|l|}{ Ethnicity } \\
\hline White UK† & 263576 & $246183(93.4)$ & 240432 (91.2) \\
\hline Not known/undisclosed & 6315 & $5492(87.0)^{\star \star}$ & $4855(76.9)^{\star \star}$ \\
\hline \multicolumn{4}{|l|}{ SMR02 maternity record $\ddagger$} \\
\hline Present $†$ & 252411 & $235730(93.4)$ & \\
\hline Absent & 32210 & $28188(87.5)^{\star \star}$ & \\
\hline \multicolumn{4}{|l|}{ Attainment (highest SCQF level)§ } \\
\hline SCQF level 5 & 73001 & $66008(90.4)^{\star *}$ & $65663(89.9)^{\star *}$ \\
\hline SCQF level 6 & 95965 & $91399(95.2)^{\star \star}$ & $84830(88.4)^{\star \star}$ \\
\hline SCQF level 7-high school attainment & 44552 & $44209(99.2)^{\star \star}$ & $38222(85.8)^{\star \star}$ \\
\hline \multicolumn{4}{|l|}{ Residential SIMD at school leavingף } \\
\hline Decile 1-most deprived $\dagger$ & 32150 & $29235(90.9)$ & $28705(89.3)$ \\
\hline Decile 2 & 29047 & $26680(91.9)^{\star \star}$ & $26488(91.2)^{\star \star}$ \\
\hline Decile 3 & 28246 & $26047(92.2)^{\star \star}$ & $25631(90.7)^{\star \star}$ \\
\hline Decile 4 & 27544 & $25468(92.5)^{\star \star}$ & $24865(90.3)^{\star \star}$ \\
\hline Decile 5 & 27374 & $25485(93.1)^{\star \star}$ & 24349 (88.9) \\
\hline Decile 6 & 27276 & $25478(93.4)^{\star \star}$ & $23691(86.9)^{\star \star}$ \\
\hline Decile 2 & 23503 & $21487(91.4)$ & $21472(91.4)^{\star}$ \\
\hline Decile 3 & 35736 & $33046(92.5)^{\star \star}$ & $31916(89.3)^{\star \star}$ \\
\hline Decile 4 & 31689 & $29020(91.6)$ & $28553(90.1)$ \\
\hline Decile 5 & 25322 & $23511(92.8)^{\star \star}$ & $22244(87.8)^{\star \star}$ \\
\hline Decile 6 & 30964 & $28873(93.2)^{\star \star}$ & $26954(87.0)^{\star \star}$ \\
\hline Decile 7 & 39165 & $36452(93.1)^{\star \star}$ & $35065(89.5)^{\star}$ \\
\hline Decile 8 & 24347 & $22858(93.9)^{\star \star}$ & $21137(86.8)^{\star \star}$ \\
\hline Decile 9 & 29370 & $27148(92.4)^{\star \star}$ & $26270(89.4)^{\star \star}$ \\
\hline Decile 10 -least deprived & 31278 & $29466(94.2)^{\star *}$ & $26803(85.7)^{\star \star}$ \\
\hline
\end{tabular}

Univariate logistic regression was used to investigate the effect of each of the socio-demographic variables in turn onwhether a destination record and maternity record was present or not.

${ }^{*} \mathrm{p}<0.05$

${ }^{* *} \mathrm{p}<0.001$

†Reference category

†Potential indicator of whether individual was born in Scotland (SMR02 maternity record present) or not (SMR02 maternity record absent).

§cottish Credit and Qualifications Framework (SCQF) level descriptors are presented in table 2.

IArea deprivation measured using 2009 Scottish Index of Multiple Deprivation (SIMD) income domain deciles.

SMR, maternity inpatient and day case discharges Scottish Morbidity Records.

Scottish Government. Local authorities are responsible for submitting data collected by each school within their area to ScotXed. Information collected includes date of leaving, stage of secondary school at leaving and reason for leaving, as well as a range of demographic information, such as gender and ethnicity. The survey is run biannually in order to cover both winter and summer leaving dates during the academic year. 


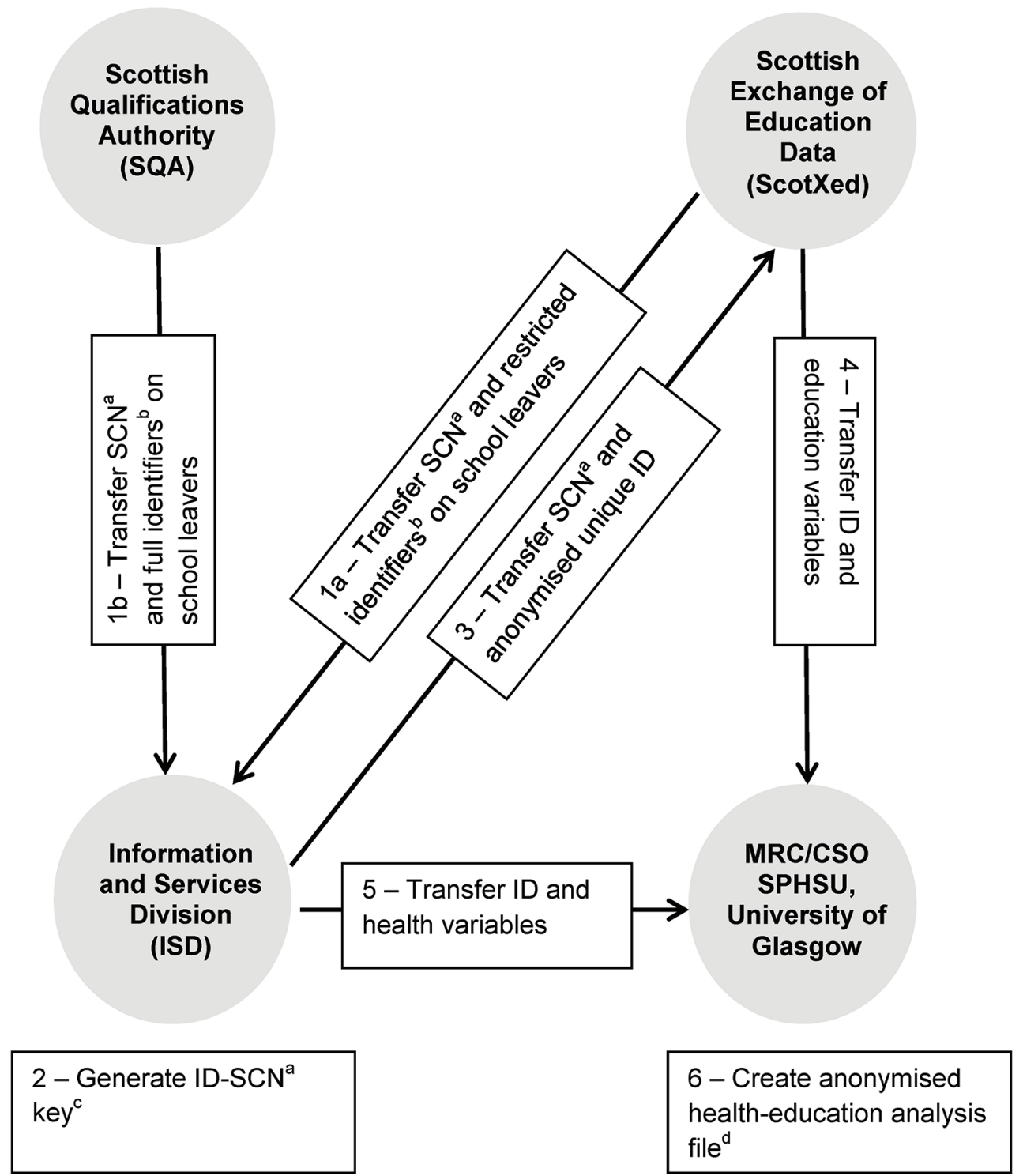

Figure 2 Data flows for linking education and health data a Scottish Candidate Number (SCN). ${ }^{b}$ Restricted identifiers include gender, date of birth and home postcode. Full identifiers include components of restricted identifiers plus forename and

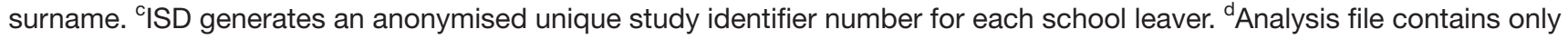
unique ID numbers and no other personal identifiers. MRC/CSO SPHSU, Medical Research Council/Chief Scientist Office Social and Public Health Sciences Unit.

A total of 284977 leavers over the 5 year study period were identified from the School Leavers Survey to form the cohort. Of these, 149 and 106 records were excluded after ScotXed later identified them as being adult learners or having match issues with their records, respectively (figure 1). A further 101 records were excluded during the data cleaning process as the individual had died before their official school leaving date as recorded in the survey-a possible result of delays in updating school records, or due to possible false links between education and health records. This left records for 284621 (99.9\% of original total) leavers in the cohort.

The age range of the cohort was approximately 14-20 years reflecting the decision of some pupils to leave on reaching the minimum school leaving age (or have been granted exceptional permission to leave) and others to continue with their studies into upper secondary.

\section{Education data}

Comprehensive educational information, including sociodemographic information, indicators of student needs, educational or non-educational support received and special school unit attendance, attendance, absence and exclusion data over time and school leaver destination information on cohort members was obtained by combining attainment data and data collected from other school surveys. In addition to the School Leavers Survey, these included the School Pupil Census, the National Statistics School Leaver Destinations Survey and the Attendance, Absence and Exclusions Survey. The School Pupil Census is an annual survey used to obtain data on publicly funded schools in Scotland and their pupils. Data are collected from school management information systems for all local authority and grant-aided schools and school centres. These data are generally of 


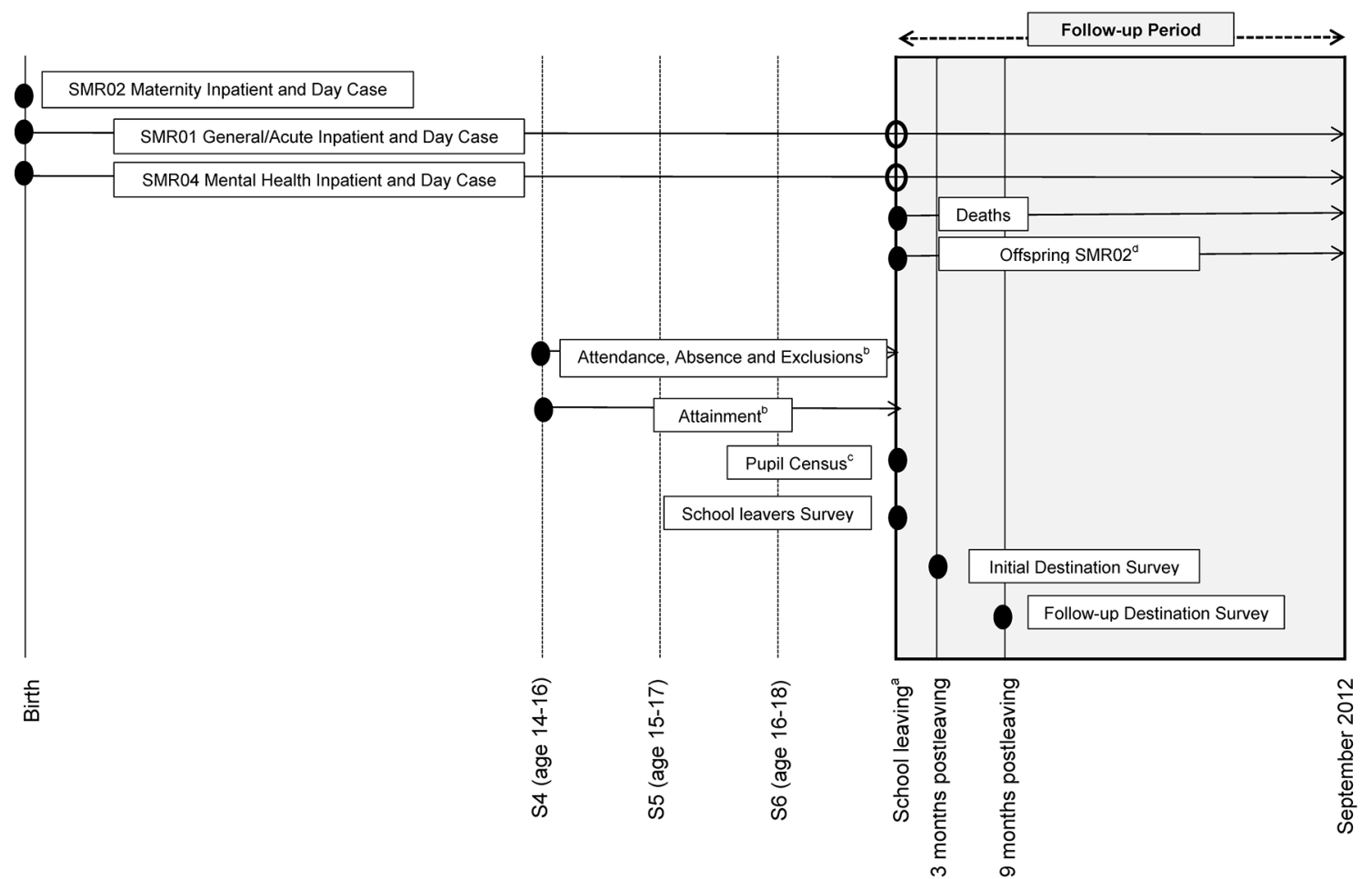

Figure 3 Timeline of health and education data obtained by life stage. a Minimum school leaving age for summer leaving (May) is turning 16years old between March and September and for winter leaving (December) is turning 16 years old between October and February. Data are for leavers during the period 2006/2007-2010/2011. ${ }^{\text {b }}$ upils may not have records for all three stages (S4-S6) if they left school prior to end of S6; left school (or took a break from school) at end of S4 and returned again in S6; or transferred to a privately funded school after S4. 'Pupil census record corresponds to the most recent record available for an individual prior to school leaving. ${ }^{\mathrm{d}} \mathrm{SMR} 02$ maternity inpatient and day case records corresponding to all children of female cohort members. SMR, Scottish Morbidity Record.

high quality since information is recorded directly from pupil enrolment forms. ${ }^{25}$ The National Statistics School Leaver Destinations Survey is used to collect information on the destination of pupils 3 months and then again at approximately 9 months after leaving school. This survey is conducted annually and is used only to obtain information on pupils who attended publicly funded schools in Scotland. The Attendance and Absence and Exclusions Surveys collect data on attendance, absence and exclusions from all local authority schools and mainstream grant aided schools in Scotland. From 2012 data collection for these surveys was changed from annually to every 2 years. $^{26}$

An area-based measure of deprivation for both home and school postcode was also available using the income domain of the 2009 Scottish Index of Multiple Deprivation. $^{27}$

Education data sets were linked using Scottish Candidate Number (SCN). The SCN is the key unique identifier within the Scottish education system. In 2006 all pupils in Scottish primary and secondary schools were assigned an SCN. Each year since, new SCNs have been allocated to primary school pupils on enrolment, to pupils re-entering the Scottish education system having originally started before SCNs were issued and to pupils at any stage entering the Scottish education system for the first time. ${ }^{28}$

Of 284621 leavers, $283742(99.7 \%)$ were further linked to a School Pupil Census record ${ }^{29} ; 284621$ (100\%) to an Attendance, Absence and Exclusion Survey record ${ }^{26}$ and $263918(92.7 \%)$ to a National Statistics School Leaver Destinations Survey record. ${ }^{30}$ The percentage of school leavers linked to a destination survey was significantly lower for individuals who were not of white UK ethnic origin $(p<0.001)$ or whose ethnicity was unknown $(p<0.001)$ and there was a clear decrease in the percentage linked as attainment decreased $\left(\mathrm{p}_{\text {trend }}<0.001\right)$ and area deprivation of home address at school leaving increased $\left(\mathrm{p}_{\text {trend }}<0.001\right)($ table 1$)$.

\section{Linkage to health data}

Prospective follow-up of participants' health outcomes by educational attainment at date of school leaving was provided by linking education data with morbidity and death records. For each of the 284621 cohort members identified by the School Leavers Survey, data linkage (figure 2) was performed by the Information and Services Division (ISD) of National Health Service (NHS) Scotland using established probability matching techniques based on the Howard Newcombe principles. ${ }^{31} 32$ Personal identifiers, including name, date of birth (DOB), gender and home postcode were supplied by ScotXed and the Scottish Qualifications Authority (SQA) for use in the linkage process. A national database of deaths and Scottish Morbidity Records (SMRs) is maintained by ISD. ${ }^{33}$ SMR data are approximately $90 \%$ accurate in the clinical coding of main condition/diagnosis based 


\section{Box 1 Variables extracted from education and health data sets for school leavers}

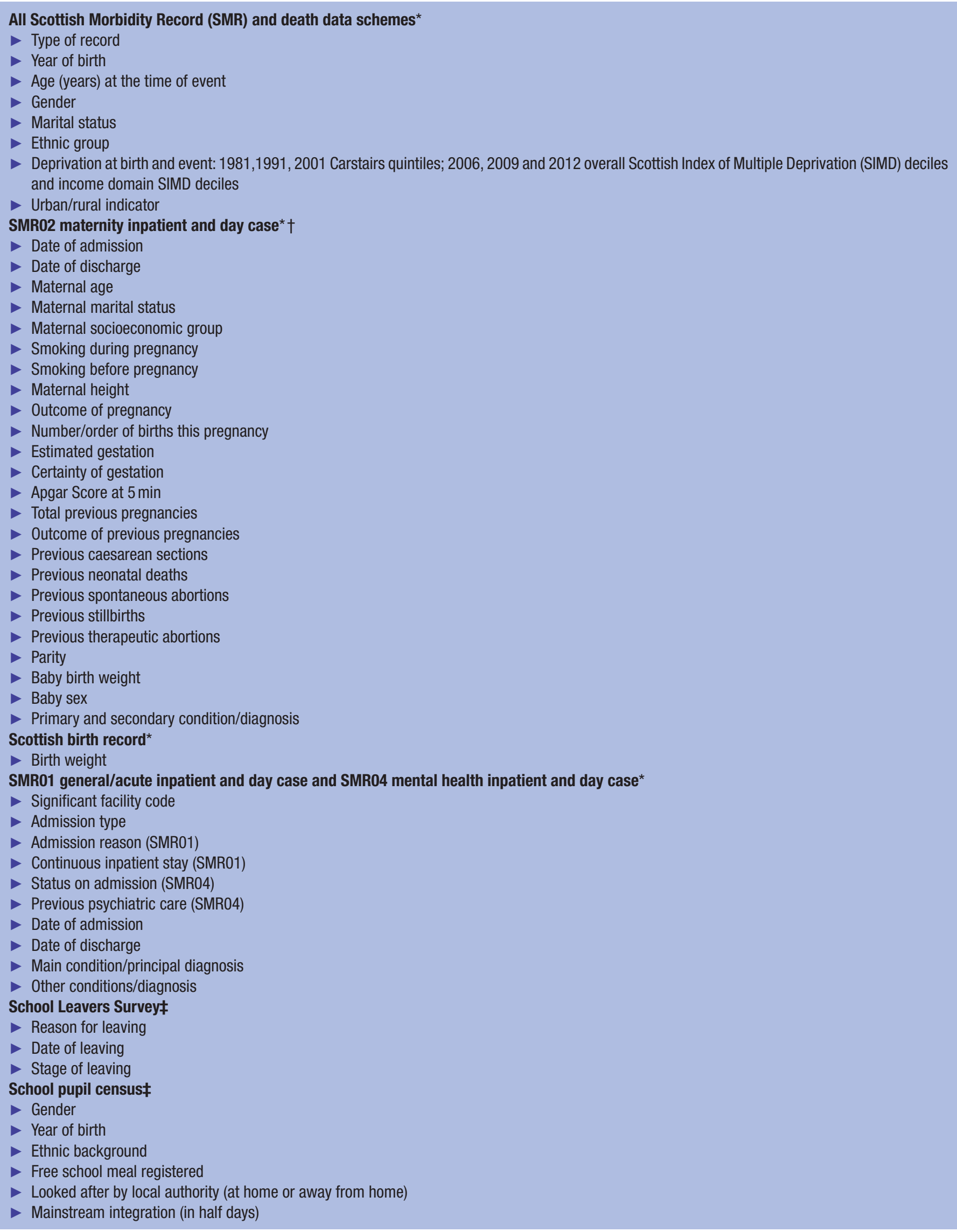




\section{Box 1 Continued}

- Attendance at special schools/units (in half days)

- Nature of additional support provided (educational or non-educational)

- Level of English

- Student need category

- Assessed (by qualified professional) or declared (by parent) disabled

Attendance, Absence and Exclusions Survey¥

- Possible attendance by year (in half days)

- Actual attendance by year (in half days)

- Absence by reason and year (in half days)

- Temporary exclusions by reason and year (in half days)

- Ever removed from register

Attainment¥

- Grades awarded by subject for Scottish Credit and Qualifications Framework (SCQF) levels 3-7

- Total tariff points§

- Number of courses at SCQF levels 1 and 2

National Statistics School Leaver Destinations Surveył

- Initial destination category

Follow-up destination category

Death*

$>$ Date of admission

Date of death

- Cause of death (underlying and contributory)

Contextual-level variablesł

- Anonymised school local authority code

- Anonymised school identifier

- Income domain of SIMD deciles for school postcode

- Income domain of SIMD deciles for home postcode at school leaving

${ }^{*}$ Data obtained from Information and Services Division (ISD) of National Health Service (NHS) Scotland. For detailed lists of all variables and codings available in each of the schemes refer to the ISD Scotland PDF pack available on the Scottish Morbidity Database section of the Administrative Data Liaison Service (ADLS) website http:// www.adls.ac.uk/nhs-scotland/scottish-morbidity-database-smr/?detail. It should be noted that this website is no longer updated. For more limited information on SMR schemes refer to SMR crib sheets in the Data Dictionary section of the ISD Scotland website http://www.ndc.scot.nhs.uk/Data-Dictionary/SMR-Crib-Sheets/index.asp. †Variables extracted from SMR02 records corresponding to both cohort members and children of female cohort members.

$\ddagger$ Data obtained from ScotXed. For a detailed guide to all information collected in each survey refer to individual survey guides by clicking on links on the ScotXed School Education website http://www.gov.scot/Topics/Statistics/ScotXed/SchoolEducation.

§Tariff points range from 1 to 120 per individual subject depending on course difficulty and award attained. A total score can be calculated by summing all points accumulated during school. Higher scores correspond to higher levels of attainment.

on the International Classification of Diseases version 10 (ICD-10) codes. $^{33} 34$ SMR schemes linked for the cohort included general/acute inpatient and day case discharges (SMR01); maternity inpatient and day case discharges (SMR02) and mental health inpatient and day case discharges (SMR04). Information on all deaths and hospital episodes extracted from the various SMR schemes, including date of admission and discharge and diagnosis is linked together to provide individual patient records $^{35}$ using the Community Health Index (CHI) number. The CHI is a population register for healthcare purposes in Scotland and assigns a unique identifying number to every person registered with a general practitioner (GP) in Scotland. ${ }^{36} 37$

The cohort includes school leavers who were born outside Scotland. Maternity and hospital records from birth until entry into Scotland for these individuals were not available. Of the 284621 leavers in the cohort, 252411 $(89 \%)$ were linked to a maternity record. Other reasons for missing maternity records include being unable to make a robust link using available identifiers and home births; however, fewer than $1 \%$ of births take place outside of hospital in Scotland. ${ }^{38}$ The percentage of school leavers with a missing maternity record was greater among individuals who were not of white UK ethnic origin $(p<0.001)$ or whose ethnicity was unknown $(\mathrm{p}<0.001)$ (table 1$)$.

In addition to requesting maternity records (SMR02) for school leavers, such records for any children born to female members of the school leavers' cohort between the date of school leaving and the end of follow-up were also requested. This allows the transgenerational effects of school education on the health of offspring to be studied.

\section{Ethical approval and governance permissions}

As the cohort was anonymised and formed using secondary data sources, ethical approval was not required. Further, consent of cohort members was not required for data linkage under the Data Protection Act. ${ }^{39}$ However, separate data applications were made to each of the three organisations providing data (SQA, ScotXed and ISD). Data sharing agreements were then issued by SQA and ScotXed for pupil identifier data and education survey 
data, respectively. As this cohort evolved through linkage of previously unlinked data sets and required access to potentially identifiable data, a further application was made to the Privacy Advisory Committee (PAC) at NHS National Services Scotland (NSS) ${ }^{40}$ in order to access hospital and death records and have them linked with education data. Since applying for these data, procedures for new applications have changed and the NSS PAC no longer receives new applications. New procedures are highlighted in the Collaboration section of this paper.

In order to help protect anonymity of cohort members, the final linked health and education analysis file supplied by ISD was stripped of all personal identifiers and contained unique study identification numbers only.

\section{Follow-up}

School leavers were followed up until September 2012. This date was selected as the end of follow-up at the time of data request in order to ensure the highest level of data completeness $(\geq 95 \%)$ for all SMR schemes requested. ${ }^{41}$ Total follow-up time was approximately 964344 person years with an average follow-up time of approximately 3.4 years. Hospital episodes or deaths occurring between school leaving and September 2012 were the health outcomes to be studied. Health outcome data were

Table 2 Scottish Credit and Qualifications Framework (SCQF) levels descriptions for attainment data received

\begin{tabular}{|c|c|c|}
\hline Level* & Award & $\begin{array}{c}\text { Age, years (stage) } \\
\text { usually taken }\end{array}$ \\
\hline 7 & Advanced higher at A-D & 17-18 (S6) \\
\hline 6 & Higher at A-D§ & $15-18(\mathrm{~S} 5, \mathrm{~S} 6)$ \\
\hline \multirow[t]{2}{*}{5} & Intermediate 2 at $A-D \|^{* *}$ & $15-18(\mathrm{~S} 5, \mathrm{~S} 6)$ \\
\hline & Standard grade (credit) ${ }^{\star \star} \dagger \dagger$ & 14-16 (S3-S4) \\
\hline \multirow[t]{2}{*}{4} & Intermediate 1 at A-D㧊 & 15-17 (S5) \\
\hline & Standard grade (general)††㧊 & 14-16 (S3-S4) \\
\hline \multirow[t]{2}{*}{$3 \dagger$} & $\begin{array}{l}\text { Standard grade } \\
\text { (foundation)††§§ }\end{array}$ & $14-16$ (S3-S4) \\
\hline & Access 3ળ§§ & 14-16 (S3, S4) \\
\hline 2 & Access $2 \prod \prod \eta \|^{\star \star \star}$ & 14+ (S3 onwards) \\
\hline 1 & Access 19††† & 14+ (S3 onwards) \\
\hline
\end{tabular}

*Level 7 corresponds to the most difficult qualification detail requested and level 1 the least difficult.

†Lowest level at which an external examination is taken.

‡New version introduced in 2015/2016.

§New version introduced in 2014/2015.

IReached final certification in 2014/2015.

${ }^{\star *}$ Replaced with National 5.

††Reached final certification in 2012/2013.

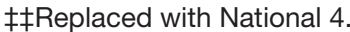

$\S \S R$ Replaced with National 3.

१ीDesigned for learners who may have additional learning support needs.

${ }^{\star \star *}$ Replaced with National 2.

†††Designed for learners with severe and profound learning difficulties.

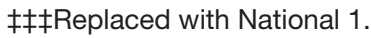

unavailable for leavers who moved outwith Scotland. Attempts were made to identify emigrants using the School Leaver Destinations Survey and records indicating deregistration from a GP. A GP deregistration record is generated when individuals register with a new GP elsewhere in the UK. If such a record was present and no further health data were present after this date then it was assumed that the individual had migrated out of Scotland to elsewhere in the UK. Emigration levels in Scotland generally tend to be low. ${ }^{33}$ In this cohort, $499(0.2 \%)$ individuals were identified as emigrants via the School Leaver Destinations Survey. A further 7735 (2.7\%) individuals were flagged up as potential emigrants via GP deregistration records.

\section{Characteristics of school leavers}

Figure 3 displays health and education data obtained by life stage of cohort members. Variables extracted from each of the different schemes displayed in figure 3 are presented in box 1 .

\section{Education characteristics of school leavers}

Information on all formal school qualifications attained by date of school leaving and other education-related individual-level variables (eg, student needs, attendance) was available. Area deprivation for school postcode and for home postcode at time of birth and school leaving was also available. Attainment data detailing grades awarded by subject according to the Scottish Credit and Qualifications Framework (SCQF) were obtained. There are 12 levels within the framework, where level 12 is the highest. No information on qualifications attained at levels 8 or above was requested as these are generally awarded at college or university. SCQF level 3 is the lowest level at which an external examination is taken. Details of SCQF levels are given in table 2. There has been an overhaul of qualifications since 2013/2014. As this is outside the range of dates for this cohort of leavers (2006/2007$2010 / 2011$ ), table 2 refers to qualifications taken prior to this change. A comparison of qualifications and how they have changed over time can be found in the SQA SCQF interactive ready reckoner. ${ }^{42}$

Descriptive statistics for sociodemographic and educational characteristics of school leavers by highest qualification attained are presented in tables 3, 4, 5 and 6 . Table 3 demonstrates that four per cent of school leavers during the period 2006/2007 to 2010/2011 failed to achieve any passes at SCQF level 3 or above. This percentage was significantly higher among boys (4\%) than girls $(3 \%) \quad(p<0.001)$. Although ethnic minority groups significantly outperformed white UK school leavers, with a higher proportion achieving at least one pass at SCQF levels $6(\mathrm{p}<0.001)$ and $7(\mathrm{p}<0.001)(59 \%$ vs $49 \%$ ), the proportion of leavers with no passes at SCQF level 3 or better was also significantly higher among ethnic minority groups ( $5 \%$ vs $4 \%, \mathrm{p}<0.001)$.

The number of school leavers failing to achieve any passes at SCQF level 3 or above was also significantly 


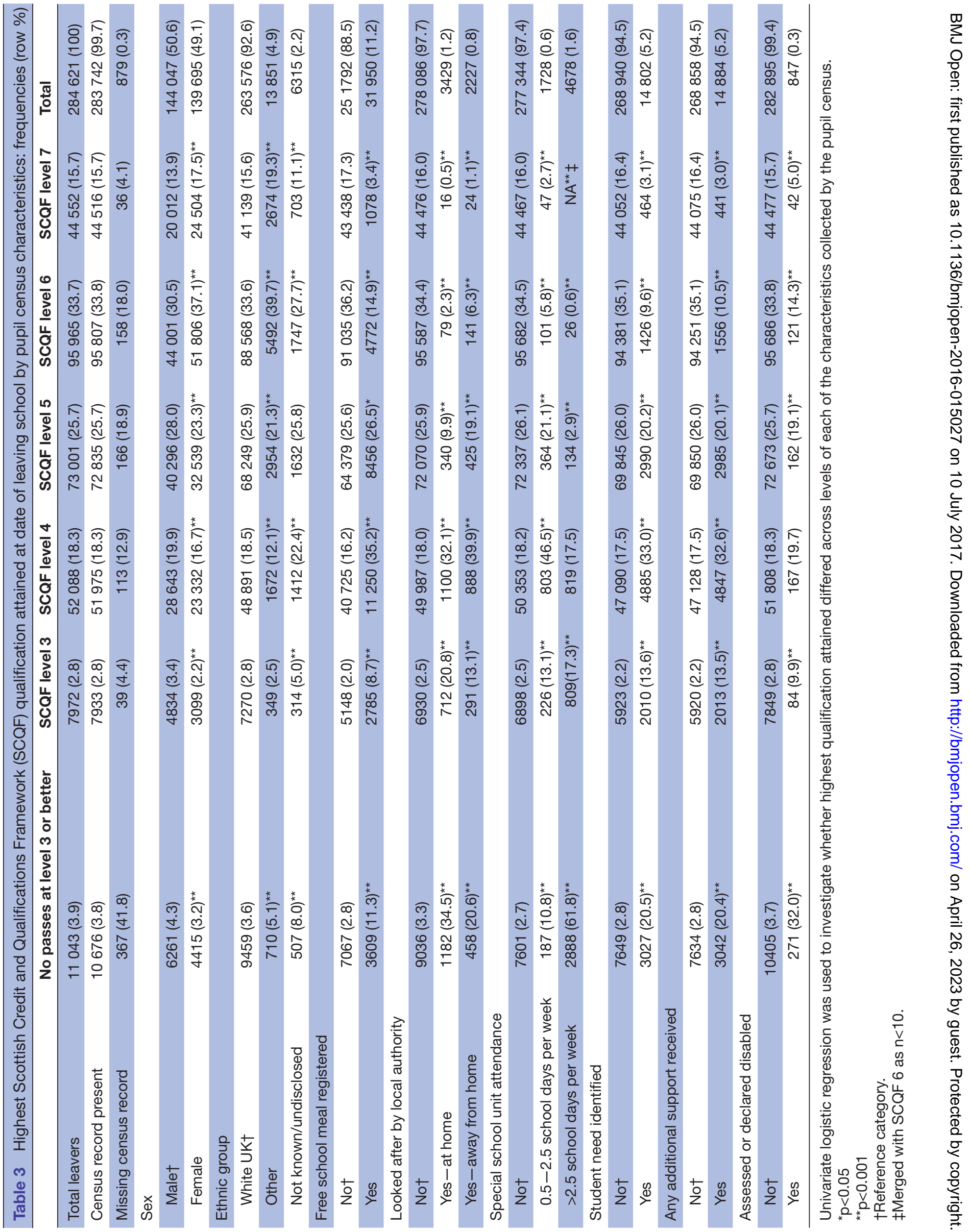




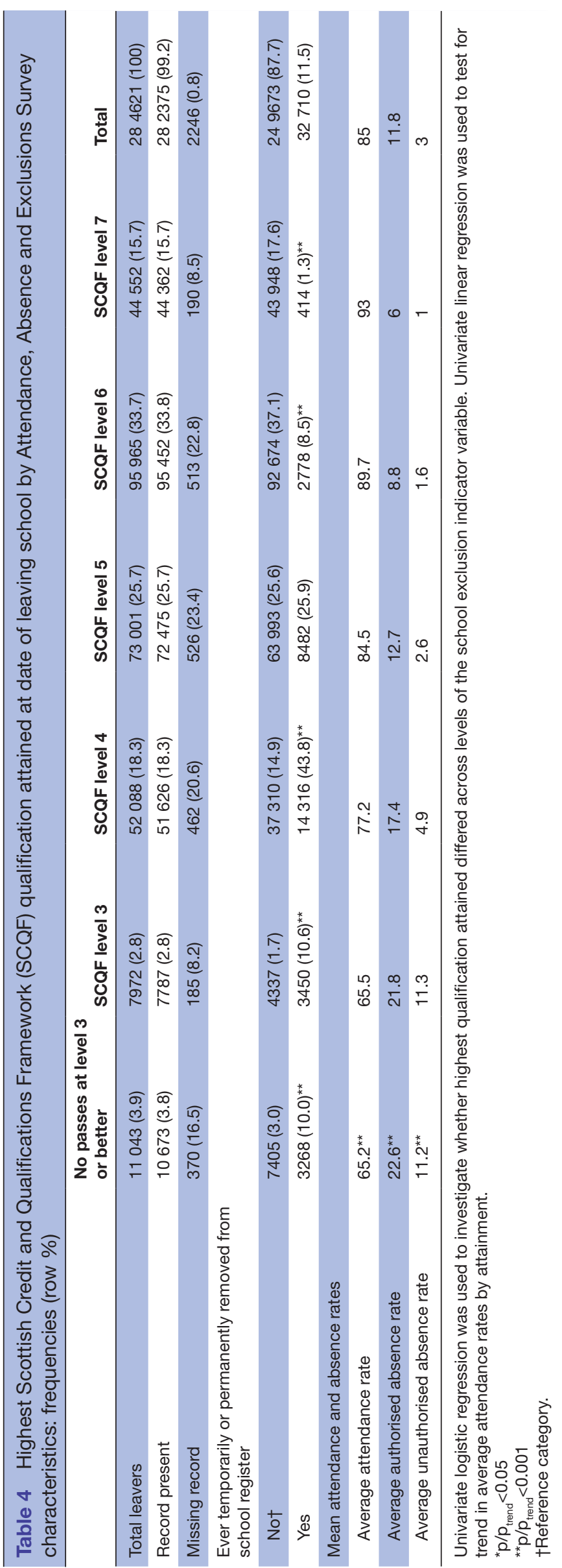

higher for those who received free school meals $(11 \%$, $\mathrm{p}<0.001)$, were looked after by the local authority either at home $(35 \%, \mathrm{p}<0.001)$ or away from home $(21 \%$, $\mathrm{p}<0.001)$, attended a special school unit $(11 \%$ for $0.5-2.5$ school days, $\mathrm{p}<0.001$ and $62 \%$ for more than half of school days per week, $\mathrm{p}<0.001)$, were identified as having additional learning needs $(21 \%, \mathrm{p}<0.001)$, received extra educational or non-educational learning support (20\%, $\mathrm{p}<0.001)$, were assessed or declared disabled $(32 \%$, $\mathrm{p}<0.001)$ and had ever been temporarily or permanently excluded from school ( $10 \%$ (table 4$), \mathrm{p}<0.001)$.

A significantly increasing trend in educational attainment and average attendance rate $(\mathrm{p}<0.001)$ was observed in table 4, with an average attendance rate of $65 \%$ for those who failed to achieve any passes at SCQF level 3 or above.

Deprivation at birth was significantly negatively associated with highest SCQF level attained at school leaving $(p<0.001$; table 5$)$. Eight per cent of school leavers in the most deprived category at birth failed to achieve any passes at SCQF level 3 or above compared with only one per cent in the least deprived category. Deprivation at school leaving had a similar effect on educational attainment $(\mathrm{p}<0.001)$. Those who attended schools in the most deprived areas were also significantly more likely to fail to achieve any passes at SCQF level 3 or above $(9 \%)$ when compared with schools in the least deprived areas $(2 \%)(\mathrm{p}<0.001)$. Table 6 presents destinations of school leavers and demonstrates that the proportion entering higher education significantly increased as highest SCQF qualification attained at date of leaving school increased $(p<0.001)$. Correspondingly, the proportion of school leavers not in education, employment or training significantly decreased as the highest SCQF qualification attained at date of leaving school increased $(p<0.001)$.

\section{Health characteristics of school leavers}

Key data requested from SMR01 and SMR04 schemes included admission type (routine/urgent/emergency), principal and secondary diagnoses, and date of admission and discharge. Mortality records provided information on date of death and primary and secondary causes of death. For birth record data, variables relating to mother, birth and baby were requested from the SMR02 scheme for both cohort members' birth and births for any children of female cohort members. Birth weight data were requested from the Scottish Birth Record (SBR) scheme. This allowed birth weight to be identified for each individual born from a multiple pregnancy. SBR data were only requested for cohort members and not for children of female cohort members.

Cause-specific morbidity and mortality rates for the cohort by highest qualification attained are presented in tables 7, 8, 9 and 10 . Total mortality rate was generally low with a rate of 47 deaths per 100000 person years at risk (PYAR; table 7). There were clear significant decreasing gradients $(\mathrm{p}<0.001)$ across all-cause and cause-specific 
Table 5 Highest Scottish Credit and Qualifications Framework (SCQF) qualification attained at date of leaving by home deprivation at birth and school leaving and school deprivation: frequencies (row \%)

\section{No passes \\ at level 3 or \\ better}

SCQF level 3 SCQF level 4

SCQF level 5

SCQF level 6

SCQF level 7 Total

\begin{tabular}{|c|c|c|c|c|c|c|c|}
\hline \multicolumn{8}{|c|}{ Home deprivation at birth $\dagger$} \\
\hline $\begin{array}{l}\text { Decile 1- } \\
\text { most deprived }\end{array}$ & $3237(8.0)^{\star *}$ & $2477(6.1)^{\star \star}$ & $12199(30.2)^{\star \star}$ & $11734(29.0)^{\star \star}$ & $8765(21.7)^{\star \star}$ & $2012(5.0)^{\star \star}$ & $40424(14.2)$ \\
\hline Decile 2 & 1645 (5.2) & $1454(4.6)$ & 8262 (26.3) & 9380 (29.9) & 8284 (26.4) & 2356 (7.5) & 31381 (11.0) \\
\hline Decile 3 & $1012(3.7)$ & 919 (3.4) & $6199(22.8)$ & 7938 (29.2) & $8383(30.8)$ & 2769 (10.2) & $27220(9.6)$ \\
\hline Decile 4 & $737(2.9)$ & $669(2.7)$ & $5136(20.4)$ & 7277 (28.9) & $8328(33.1)$ & 3049 (12.1) & $25196(8.9)$ \\
\hline Decile 5 & $573(2.5)$ & $530(2.3)$ & $4144(17.8)$ & $6484(27.8)$ & $8143(34.9)$ & 3469 (14.9) & $23343(8.2)$ \\
\hline Decile 6 & $465(2.1)$ & $397(1.8)$ & 3195 (14.6) & $5573(25.5)$ & $8322(38.1)$ & $3867(17.7)$ & $21819(7.7)$ \\
\hline Decile 7 & $373(1.8)$ & $257(1.2)$ & 2707 (12.9) & $4928(23.4)$ & $8453(40.1)$ & 4349 (20.6) & $21067(7.4)$ \\
\hline Decile 8 & $292(1.5)$ & $202(1.0)$ & $2075(10.5)$ & $4196(21.3)$ & $8212(41.6)$ & $4757(24.1)$ & $19734(6.9)$ \\
\hline Decile 9 & $211(1.1)$ & $134(0.7)$ & $1634(8.4)$ & 3735 (19.3) & $8326(43.0)$ & $5329(27.5)$ & $19369(6.8)$ \\
\hline $\begin{array}{l}\text { Decile } 10- \\
\text { least deprived }\end{array}$ & $195(1.1)$ & $90(0.5)$ & $1289(7.0)$ & $3344(18.1)$ & 7994 (43.3) & $5534(30.0)$ & $18446(6.5)$ \\
\hline Missing & $2303(6.3)$ & $843(2.3)$ & $5248(14.3)$ & $8412(23.0)$ & $12755(34.8)$ & 7061 (19.3) & $36622(12.9)$ \\
\hline \multicolumn{8}{|c|}{ Home deprivation at school leaving date $\dagger$} \\
\hline $\begin{array}{l}\text { Decile } 1- \\
\text { most deprived }\end{array}$ & $3132(9.7)^{\star *}$ & $2221(6.9)^{\star \star}$ & $9851(30.6)^{\star \star}$ & $9109(28.3)^{\star \star}$ & $6583(20.5)^{\star *}$ & $1254(3.9)^{\star *}$ & $32150(11.3)$ \\
\hline Decile 2 & $1815(6.3)$ & $1527(5.3)$ & $8057(27.7)$ & $8727(30.0)$ & $7091(24.4)$ & $1830(6.3)$ & $29047(10.2)$ \\
\hline Decile 3 & $1323(4.7)$ & $1161(4.1)$ & $6993(24.8)$ & 8457 (29.9) & 7969 (28.2) & $2343(8.3)$ & $28246(9.9)$ \\
\hline Decile 4 & $1041(3.8)$ & $842(3.1)$ & $5925(21.5)$ & $7991(29.0)$ & $8743(31.7)$ & 3002 (10.9) & $27544(9.7)$ \\
\hline Decile 5 & $825(3.0)$ & $599(2.2)$ & $5304(19.4)$ & $7716(28.2)$ & $9299(34.0)$ & 3631 (13.3) & $27374(9.6)$ \\
\hline Decile 6 & $653(2.4)$ & $529(1.9)$ & $4316(15.8)$ & $7176(26.3)$ & $10011(36.7)$ & $4591(16.8)$ & $27276(9.6)$ \\
\hline Decile 7 & $575(2.1)$ & $375(1.3)$ & $3823(13.7)$ & $6803(24.4)$ & $10871(38.9)$ & $5485(19.6)$ & $27932(9.8)$ \\
\hline Decile 8 & $452(1.6)$ & $299(1.1)$ & 3107 (11.1) & 6277 (22.5) & $11242(40.2)$ & 6585 (23.6) & $27962(9.8)$ \\
\hline Decile 9 & $387(1.4)$ & $182(0.7)$ & $2410(8.7)$ & 5508 (19.8) & $12073(43.4)$ & 7265 (26.1) & $27825(9.8)$ \\
\hline $\begin{array}{l}\text { Decile } 10- \\
\text { least deprived }\end{array}$ & $335(1.2)$ & $122(0.5)$ & $1812(6.7)$ & $4673(17.4)$ & $11543(42.9)$ & 8435 (31.3) & $26920(9.5)$ \\
\hline Missing & 505 (21.5) & $115(4.9)$ & $490(20.9)$ & $564(24.1)$ & $540(23.0)$ & $131(5.6)$ & $2345(0.8)$ \\
\hline \multicolumn{8}{|c|}{ School deprivation† } \\
\hline $\begin{array}{l}\text { Decile 1- } \\
\text { most deprived }\end{array}$ & $1204(9.1)^{\star \star}$ & $789(6.0)^{\star \star}$ & $3322(25.1)^{\star \star}$ & $3627(27.4)^{\star \star}$ & $3380(25.5)^{\star *}$ & $925(7.0)^{\star \star}$ & $13247(4.7)$ \\
\hline Decile 2 & $1600(6.8)$ & $1164(5.0)$ & 5244 (22.3) & $6321(26.9)$ & $6976(29.7)$ & $2198(9.4)$ & $23503(8.3)$ \\
\hline Decile 3 & $1662(4.7)$ & $1309(3.7)$ & 7632 (21.4) & $10194(28.5)$ & $11033(30.9)$ & 3906 (10.9) & 35736 (12.6) \\
\hline Decile 4 & $1253(4.0)$ & $828(2.6)$ & 6464 (20.4) & $8650(27.3)$ & $10356(32.7)$ & $4138(13.1)$ & $31689(11.1)$ \\
\hline Decile 5 & 799 (3.2) & $693(2.7)$ & 4766 (18.8) & 6668 (26.3) & $8739(34.5)$ & 3657 (14.4) & $25322(8.9)$ \\
\hline Decile 6 & $910(2.9)$ & $680(2.2)$ & $5160(16.7)$ & $7784(25.1)$ & $11095(35.8)$ & 5335 (17.2) & 30964 (10.9) \\
\hline Decile 7 & $1122(2.9)$ & $936(2.4)$ & $6911(17.6)$ & $10117(25.8)$ & $13693(35.0)$ & $6386(16.3)$ & $39165(13.8)$ \\
\hline Decile 8 & $814(3.3)$ & $437(1.8)$ & $3906(16.0)$ & $5930(24.4)$ & $8671(35.6)$ & 4589 (18.8) & 24347 (8.6) \\
\hline Decile 9 & $1087(3.7)$ & 729 (2.5) & $5018(17.1)$ & $7182(24.5)$ & 10147 (34.5) & 5207 (17.7) & 29370 (10.3) \\
\hline $\begin{array}{l}\text { Decile } 10- \\
\text { least deprived }\end{array}$ & $592(1.9)$ & 407 (1.3) & 3665 (11.7) & 6528 (20.9) & $11875(38.0)$ & 8211 (26.3) & $31278(11.0)$ \\
\hline
\end{tabular}

Univariate logistic regression was used to investigate whether highest qualification attained differed across levels of deprivation.

${ }^{*} p_{\text {trend }}<0.05$

${ }^{* \star} p_{\text {trend }}<0.001$

†Based on 2009 Scottish Index of Multiple Deprivation (SIMD) income domain. 
mortality rates as the highest qualification attained by school leaving increased. The total admission rate for SMR01 admissions was 10272 admissions per 100000 PYAR (table 8).
Cause-specific rates were greatest for diseases of the digestive system and accidents (1256 and 1012 admissions per 100000 PYAR, respectively). There was a significant decreasing trend in rate of admission as

Table 6 School leaver destination survey characteristics by highest Scottish Credit and Qualifications Framework (SCQF) qualification attained at date of leaving school: frequencies (column \%)

\begin{tabular}{|c|c|c|c|c|c|c|c|}
\hline & $\begin{array}{l}\text { No passes } \\
\text { at level } 3 \text { or } \\
\text { better }\end{array}$ & $\begin{array}{l}\text { SCQF level } \\
3\end{array}$ & SCQF level 4 & SCQF level 5 & SCQF level 6 & SCQF level 7 & Total \\
\hline Total leavers & $11043(3.9)$ & $7972(2.8)$ & 52088 (18.3) & 73001 (25.7) & 95965 (33.7) & 44552 (15.7) & $284621(100)$ \\
\hline $\begin{array}{l}\text { Leaver } \\
\text { destination } \\
\text { record present }\end{array}$ & $7823(70.8)$ & $6930(86.9)$ & 47549 (91.3) & $66008(90.4)$ & 91399 (95.2) & 44209 (99.2) & 263918 (92.7) \\
\hline $\begin{array}{l}\text { Missing leaver } \\
\text { destination } \\
\text { record }\end{array}$ & $3220(29.2)$ & $1042(13.1)$ & $4539(8.7)$ & $6993(9.6)$ & $4566(4.8)$ & $343(0.8)$ & $20703(7.3)$ \\
\hline \multicolumn{8}{|l|}{$\begin{array}{l}\text { Initial leaver } \\
\text { destinations }\end{array}$} \\
\hline $\begin{array}{l}\text { Higher } \\
\text { education }\end{array}$ & $44(0.4)^{\star \star}$ & $16(0.2)$ & $375(0.7)$ & 3061 (4.2) & $49035(51.1)$ & 37689 (84.6) & $90220(31.7)$ \\
\hline $\begin{array}{l}\text { Other } \\
\text { education }\end{array}$ & $1808(16.4)^{\star \star}$ & $1683(21.1)$ & 16682 (32.0) & $28004(38.4)$ & 17935 (18.7) & $2210(5.0)$ & $68322(24.0)$ \\
\hline $\begin{array}{l}\text { Training \& } \\
\text { development }\end{array}$ & $1362(12.3)^{\star \star}$ & 1369 (17.2) & 6961 (13.4) & $3962(5.4)$ & $597(0.6)$ & $59(0.1)$ & $14310(5.0)$ \\
\hline $\begin{array}{l}\text { Paid } \\
\text { employment }\end{array}$ & $950(8.6)^{\star \star}$ & $880(11.0)$ & 12008 (23.1) & 22251 (30.5) & $18040(18.8)$ & $2868(6.4)$ & 56997 (20.0) \\
\hline $\begin{array}{l}\text { Voluntary } \\
\text { work }\end{array}$ & $26(0.2)^{\star \star}$ & $32(0.4)$ & $112(0.2)$ & $129(0.2)$ & $286(0.3)$ & $215(0.5)$ & $800(0.3)$ \\
\hline NEET† & $3301(29.9)^{\star \star}$ & 2777 (34.8) & 10708 (20.6) & $7872(10.8)$ & $4891(5.1)$ & 1008 (2.3) & 30557 (10.7) \\
\hline Emigrated & $45(0.4)^{\star \star}$ & $20(0.3)$ & $131(0.3)$ & $176(0.2)$ & $136(0.1)$ & $28(0.1)$ & $536(0.2)$ \\
\hline $\begin{array}{l}\text { Other or } \\
\text { unknown }\end{array}$ & $287(2.6)^{\star \star}$ & $153(1.9)$ & $572(1.1)$ & $553(0.8)$ & $479(0.5)$ & $132(0.3)$ & $2176(0.8)$ \\
\hline \multicolumn{8}{|l|}{$\begin{array}{l}\text { Follow-up leaver } \\
\text { destinations }\end{array}$} \\
\hline $\begin{array}{l}\text { Higher } \\
\text { education }\end{array}$ & $40(0.4)^{\star \star}$ & $12(0.2)$ & $289(0.6)$ & $2508(3.4)$ & 45935 (47.9) & 36639 (82.2) & $85423(30.0)$ \\
\hline $\begin{array}{l}\text { Other } \\
\text { education }\end{array}$ & $1373(12.4)^{\star *}$ & $1286(16.1)$ & $13582(26.1)$ & 24857 (34.1) & $16742(17.5)$ & $2107(4.7)$ & $59947(21.1)$ \\
\hline $\begin{array}{l}\text { Training \& } \\
\text { development }\end{array}$ & $897(8.1)^{\star \star}$ & $1013(12.7)$ & $5057(9.7)$ & $2723(3.7)$ & $487(0.5)$ & $36(0.1)$ & $10213(3.6)$ \\
\hline $\begin{array}{l}\text { Paid } \\
\text { employment }\end{array}$ & $1076(9.7)^{\star \star}$ & $1012(12.7)$ & $14202(27.3)$ & 25950 (35.6) & 22632 (23.6) & $4029(9.0)$ & $68901(24.2)$ \\
\hline $\begin{array}{l}\text { Voluntary } \\
\text { work }\end{array}$ & $45(0.4)$ & $44(0.6)$ & $160(0.3)$ & $178(0.2)$ & $315(0.3)$ & $244(0.6)$ & $986(0.4)$ \\
\hline NEET† & $3878(35.1)^{\star *}$ & $3258(40.9)$ & $13030(25.0)$ & 8638 (11.8) & $4442(4.6)$ & 1001 (2.3) & 34247 (12.0) \\
\hline Emigrated & $59(0.5)^{\star \star}$ & $31(0.4)$ & $178(0.3)$ & $218(0.3)$ & $206(0.2)$ & $38(0.1)$ & $730(0.3)$ \\
\hline $\begin{array}{l}\text { Other or } \\
\text { unknown } \neq\end{array}$ & $455(4.1)^{\star \star}$ & $274(3.4)$ & $1051(2.0)$ & 936 (1.3) & $640(0.7)$ & $115(0.3)$ & 3471 (1.2) \\
\hline
\end{tabular}

Univariate logistic regression was used to test for trend in leaver destination by attainment.

${ }^{*} p_{\text {trend }}<0.05$

${ }^{* *} \mathrm{p}_{\text {trend }}<0.001$

†Not in education, employment or training.

łlncludes 22 deceased individuals.

NEET, not in education, employment or training. 
Table 7 Cause of death by highest Scottish Credit and Qualifications Framework (SCQF) qualification at school leaving (rates per 100000 person years at risk)

\begin{tabular}{|c|c|c|c|c|c|c|c|c|}
\hline & $\begin{array}{l}\text { Number of } \\
\text { events }\end{array}$ & $\begin{array}{l}\text { No passes at } \\
\text { level } 3 \text { or better }\end{array}$ & $\begin{array}{l}\text { SCQF } \\
\text { level } 3\end{array}$ & $\begin{array}{l}\text { SCQF } \\
\text { level } 4\end{array}$ & $\begin{array}{l}\text { SCQF } \\
\text { level } 5\end{array}$ & $\begin{array}{l}\text { SCQF } \\
\text { level } 6\end{array}$ & $\begin{array}{l}\text { SCQF } \\
\text { level 7† }\end{array}$ & Total \\
\hline \multicolumn{9}{|l|}{ Deaths } \\
\hline Accidents and assault & $186^{\star \star}$ & 35 & 84 & 32 & 17 & 11 & 8 & 19 \\
\hline Suicide (undetermined and self harm) & $120^{\star \star}$ & 40 & 48 & 20 & 11 & 6 & & 12 \\
\hline
\end{tabular}

Univariate Poisson regression was used to test for trend in each of the health outcomes by attainment.

${ }^{*} \mathrm{p}_{\text {trend }}<0.05$

${ }^{* *} p_{\text {trend }}<0.001$

†Merged with SCQF 6 as $n<10$

†Includes deaths with ICD-10 codes other than for accident, assault or suicide.

ICD-10 codes for outcomes presented in the table are as follows: accidents V01-X59, Y85, Y86 and assault X85-Y09; suicide (undetermined and self-harm) X60-X84, Y10-Y34, Y870 Y872.

highest qualification attained increased for all diagnoses other than benign neoplasms $(\mathrm{p}=0.070)$, acute tonsillitis $(\mathrm{p}=0.380)$, other diseases of the upper respiratory tract ( $\mathrm{p}=0.881)$ as well as Crohn's disease and ulcerative colitis, where rates were significantly increasing as the highest qualification attained increased.

The total admission rate for psychiatric and learning disabilities hospitals and units (SMR04) was 204 admissions per 100000 PYAR (table 9). The greatest cause-specific admission rate was for mood (affective) disorders (55 admission per 100000 PYAR), in particular for depressive episodes (38 admissions per 100000 PYAR). Again, the significant decreasing trend $(p<0.001)$ in admission rates with increasing attainment can be observed for all cause-specific admissions. There were slightly elevated rates in the highest attainment group (SCQF 7) for schizophrenia and general psychiatric examination.

The total pregnancy rate among female cohort members (including live births and stillbirths, deaths and all abortions) was 203 per 1000 women (table 10), of which 158 per 1000 women were first ever pregnancies. Mean age at first pregnancy across the whole cohort was 18 years with the highest qualified women (SCQF 7) experiencing first pregnancy significantly later (age 19 years) than the least qualified (age 18 years) on average. The medical abortion rate was 83 abortions per 1000 women. Total rates of 5 per 1000 total births were observed for stillbirths, 7 per 1000 total births for perinatal deaths and 2 per 1000 live births for neonatal deaths. There was no significant effect of educational attainment on the multiple birth rate, with the overall rate being 7 per 1000 maternities. Finally, there was a significant decreasing trend in low birth weight $(<2500 \mathrm{~g})$ rate of offspring as attainment increased, with a rate of 8 low birthweight babies per 100 live births in the least qualified group compared with 5 in the most qualified group (SCQF 7).

\section{FINDINGS TO DATE AND FUTURE PLANS}

The Scottish school leavers cohort has involved recent novel linkage of education and health data, therefore key findings and publications to date are limited. Due to the young age of the cohort, research has focused mainly on mental health outcomes. Initial work to date includes investigation of educational attainment as a mediator of the relationship between low birth weight and attempted and completed suicide in young adulthood. This work showed that educational attainment accounted for more than half of the effect of birth weight on attempted and completed suicide in young adults. ${ }^{43}$ Educational attainment remained strongly associated with suicidal behaviour, even on full adjustment for a wide range of early life and maternal, educational and childhood mental and physical health risk factors.

Other work has included investigating educational inequalities in birth weight of first-born children of female cohort members. ${ }^{44}$ This work showed that adjustment for maternal birth weight, childhood health, and educational and antenatal risk factors explained more than half of the effect of educational attainment on the odds of having a low birthweight baby. In particular, this work suggested that targeting young women during pregnancy and improving antenatal risk factors (eg, smoking) has the potential to contribute to a decrease in educational differences in the risk of low birthweight offspring.

Future plans mainly include continuing to study the various roles played by educational attainment on mental health outcomes in young adulthood, such as whether deterioration in attainment over time can predict later adverse mental health outcomes including, for example, suicidal behaviour or substance abuse. The availability of hospital records from birth allows any deterioration in childhood mental and physical health, which may confound associations between the exposure and outcome, to be controlled for. Other future plans may also involve linkage to prescription data and the 
Table 8 General acute inpatient and day case admissions by highest Scottish Credit and Qualifications Framework (SCQF) qualification at school leaving (rates per 100000 person years at risk)

\begin{tabular}{|c|c|c|c|c|c|c|c|c|}
\hline & $\begin{array}{l}\text { Number of } \\
\text { events }\end{array}$ & $\begin{array}{l}\text { No passes } \\
\text { at level } 3 \text { or } \\
\text { better }\end{array}$ & $\begin{array}{l}\text { SCQF } \\
\text { level } 3\end{array}$ & $\begin{array}{l}\text { SCQF } \\
\text { level } 4\end{array}$ & $\begin{array}{l}\text { SCQF } \\
\text { level } 5\end{array}$ & $\begin{array}{l}\text { SCQF } \\
\text { level } 6\end{array}$ & $\begin{array}{l}\text { SCQF } \\
\text { level } 7\end{array}$ & Total \\
\hline All admissions postschool leaving & $99027^{\star \star}$ & 16319 & 14739 & 12984 & 11126 & 8628 & 6100 & 10272 \\
\hline Intentional self-harm† & $4697^{\star \star}$ & 1408 & 1481 & 891 & 476 & 212 & 115 & 487 \\
\hline Assault $†$ & $2709^{\star *}$ & 793 & 812 & 533 & 287 & 108 & 63 & 281 \\
\hline Alcohol-related $\dagger$ & $4769^{\star \star}$ & 1361 & 1697 & 909 & 450 & 210 & 164 & 495 \\
\hline Drug misuse $†$ & $831^{\star *}$ & 369 & 399 & 175 & 68 & 17 & 11 & 86 \\
\hline Neoplasms & $4038^{\star \star}$ & 868 & 267 & 321 & 366 & 510 & 341 & 419 \\
\hline Malignant & $2780^{\star *}$ & 759 & 194 & 188 & 220 & 379 & 226 & 288 \\
\hline Benign & 1164 & 87 & 62 & 118 & 134 & 126 & 111 & 121 \\
\hline Accidents & $9758^{\star \star}$ & 1663 & 1990 & 1447 & 1126 & 696 & 544 & 1012 \\
\hline Road traffic accidents & $1740^{\star \star}$ & 248 & 256 & 254 & 227 & 126 & 84 & 180 \\
\hline All other accidents & $8018^{\star \star}$ & 1415 & 1734 & 1192 & 899 & 570 & 460 & 831 \\
\hline Diseases of the respiratory system & $7773^{\star \star}$ & 892 & 772 & 951 & 926 & 741 & 519 & 806 \\
\hline Acute tonsillitis & 3136 & 176 & 263 & 379 & 379 & 320 & 220 & 325 \\
\hline $\begin{array}{l}\text { Other diseases of upper respiratory } \\
\text { tract }\end{array}$ & 2271 & 176 & 194 & 244 & 266 & 236 & 193 & 235 \\
\hline Asthma & $910^{* *}$ & 112 & 117 & 145 & 129 & 63 & 24 & 94 \\
\hline Diseases of the digestive system & $12110^{\star \star}$ & 1817 & 1394 & 1341 & 1300 & 1207 & 980 & 1256 \\
\hline $\begin{array}{l}\text { Diseases of teeth and supporting } \\
\text { structures }\end{array}$ & $2619^{\star *}$ & 605 & 249 & 253 & 258 & 273 & 226 & 272 \\
\hline Diseases of appendix & $1477^{\star}$ & 154 & 143 & 177 & 171 & 131 & 140 & 153 \\
\hline Crohn's disease and ulcerative colitis & $2044^{\star *}$ & 97 & 227 & 178 & 221 & 249 & 190 & 212 \\
\hline Diseases of the genitourinary system & $7393^{\star *}$ & 793 & 1101 & 898 & 826 & 706 & 544 & 767 \\
\hline $\begin{array}{l}\text { Symptoms, signs and abnormal } \\
\text { clinical and lab findings, not elsewhere } \\
\text { classified }\end{array}$ & $13286^{* *}$ & 2095 & 2001 & 1923 & 1525 & 1069 & 733 & 1378 \\
\hline Abdominal and pelvic pain & $7478^{\star *}$ & 952 & 1174 & 1160 & 874 & 585 & 373 & 775 \\
\hline Pain in throat and chest & $1014^{\star *}$ & 186 & 157 & 144 & 123 & 82 & 40 & 105 \\
\hline Headache & $927^{\star \star}$ & 94 & 117 & 123 & 109 & 83 & 62 & 96 \\
\hline
\end{tabular}

Univariate Poisson regression was used to test for trend in each of the health outcomes by attainment.

${ }^{*} p_{\text {trend }}<0.05$

${ }^{* \star} p_{\text {trend }}<0.001$

†Apart from intentional self-harm, assault, alcohol-related, drug misuse and accidents, admission outcomes in the table were defined if the corresponding ICD-10 codes was the primary diagnosis. Admissions for intentional self-harm, assault, alcohol-related, drug misuse and accidents were defined as such if the corresponding ICD-10 codes were primary or secondary diagnoses, therefore double-counting of some events may occur if the primary diagnosis was for something else.

ICD-10 codes for outcomes presented in the table are as follows: intentional self-harm X60-X84, Y870, Y10-Y34, Y872; assault X85-Y09, Y87; alcohol-related E244, E512, F10, G312, G621, G721, I426, K292, K70, K852, K860, O354, P043, Q860, R780, T510, T511, T519, X45, X65, Y15, Y573, Y90, Y91, Z502, Z714, Z721; drug misuse F11, F12, F13, F14, F15, F16, F18, F19; neoplasms C00-C97, D00-D09, D10-D36, D37-D4; malignant neoplasms C00-C97; benign neoplasms D10-D36; accidents V01-X59, Y85, Y86; road traffic accidents V01-V04, V06V80, V87, V89, V99; diseases of the respiratory system J00-J99; acute tonsillitis J03; other diseases of the upper respiratory tract J30-J39; asthma J45; diseases of the digestive system K00-K93; diseases of teeth and supporting structures K00-K08; diseases of appendix K35K38; Crohn's disease and ulcerative colitis K50-K51; diseases of the genitourinary system N00-N99; symptoms, signs and abnormal clinical and lab findings, not elsewhere classified R00-R99; abdominal and pelvic pain R100-R104; pain in throat and chest R070-R074; headache R51.

Scottish Primary Care Information Resource (SPIRE). ${ }^{45}$ These data schemes may provide a more representative view of some health outcomes in young adults, particularly for mental health outcomes given the shift away from inpatient psychiatric care towards primary care centres and community-based settings. ${ }^{46-48}$ SPIRE is a new resource in Scotland for extracting data from GP practice systems. ${ }^{45}$ Expected completion date for Scotland-wide installation of data extraction infrastructure for SPIRE is February 2017. 
Table 9 Mental health inpatient and day case admissions by highest Scottish Credit and Qualifications Framework (SCQF) qualification at school leaving (rates per 100000 person years at risk)

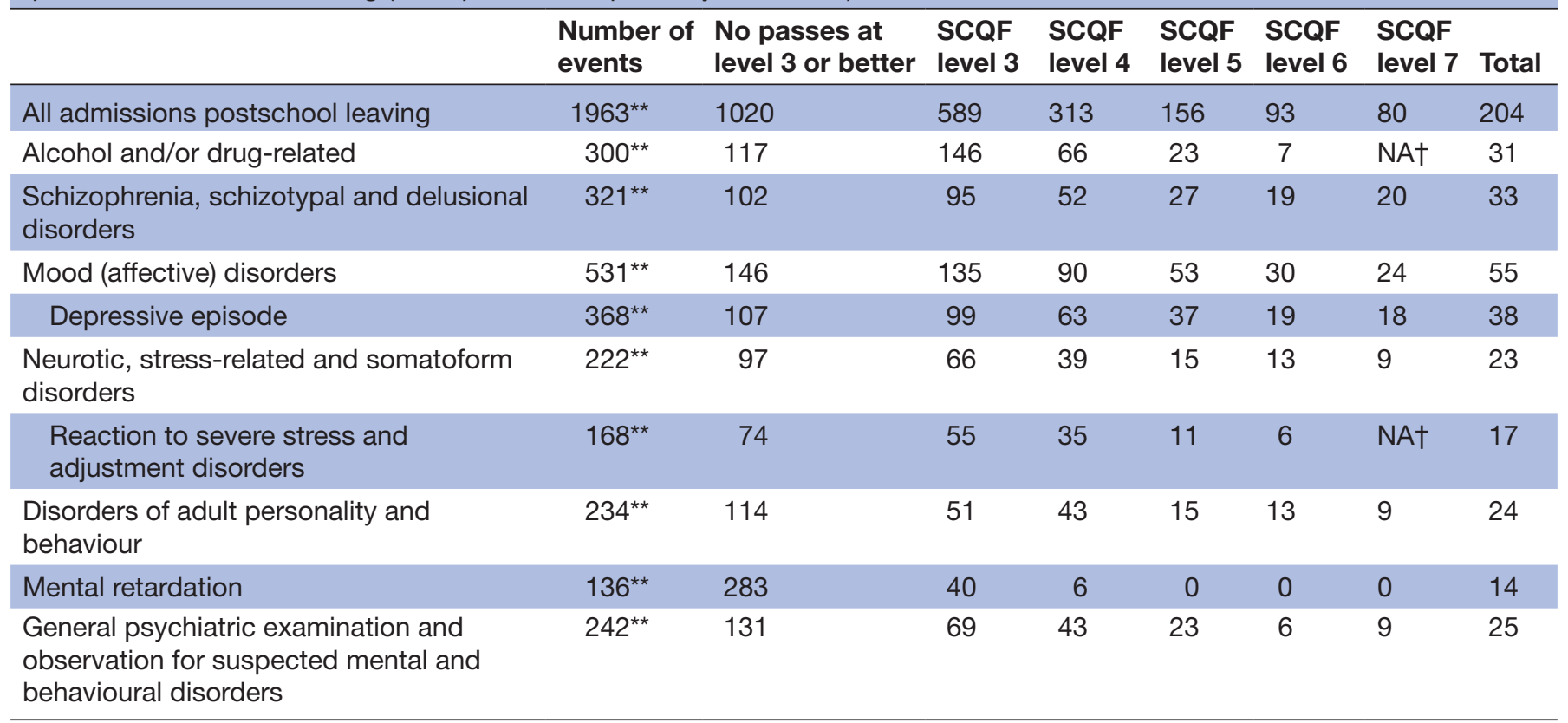

Univariate Poisson regression was used to test for trend in each of the health outcomes by attainment.

${ }^{*} \mathrm{p}_{\text {trend }}<0.05$

${ }^{* *} p_{\text {trend }}<0.001$

†Merged with SCQF 6 as $\mathrm{n}<10$

ICD-10 codes for outcomes presented in the table are as follows: Alcohol E244, E512, F10, G312, G621, G721, I426, K292, K70, K852, K860, O354, P043, Q860, R780, T510, T511, T519, X45, X65, Y15, Y573, Y90, Y91, Z502, Z714, Z721 and/or drug-related F11, F12, F13, F14, F15, F16, F18, F19; schizophrenia, schizotypal and delusional disorders F20-F30; mood (affective) disorders F30-F39; depressive episode F32F33; neurotic, stress-related and somatoform disorders F40-F48; reaction to severe stress and adjustment disorders F43-F44; disorders of adult personality and behaviour F60-F69; mental retardation F70-F79; general psychiatric examination Z004 and observation for suspected mental and behavioural disorders Z032.

NA, not applicable.

\section{STRENGTHS AND LIMITATIONS Strengths}

The main strength is access to a large, representative, prospective cohort study of all local authority secondary school leavers in Scotland through linkage of comprehensive education data with hospital and death records. Availability of data across the life course allows associations between education and health in young adults, while accounting for a wide range of other sociodemographic, biological, psychological and clinical risk factors to be studied, and causal relationships to be explored. There is the potential to extend the follow-up period through record linkage with future hospital records to study a wider range of health outcomes over the life course of this cohort. This can determine whether the association between education and health changes over the life course. As well as extending the follow-up period, there is also the possibility of extending the cohort by adding data from future leavers.

As attainment data were available by individual subject, there was great flexibility for creating various measures of attainment. In particular, a continuous measure of attainment may be created by calculating tariff scores. ${ }^{49}$ Further, there is also scope for creating measures more suited to making international comparisons of educational attainment. Information on attainment over different school stages allows for comparisons of attainment over time within an individual. Another strength was the ability to access names of pupils to use for data matching when linking with health records. Previous attempts to link education and health data have relied on limited identifiers, using residential postcode, DOB and gender only. ${ }^{50-53}$ Having a name available for this cohort guarantees a more robust match and helps eliminate problematic matching of individuals with the same postcode-DOB-gender identifiers including same-sex multiple births. ${ }^{50}$

\section{Limitations}

No information on educational qualifications taken after school leaving was available, so this study was unable to determine final achieved education. However, school attainment has been shown to be associated with a young person's likelihood of entering higher education. ${ }^{54}$

Currently, data are not available for school leavers leaving privately funded schools in Scotland. Although only a small proportion $(\sim 4 \%)^{55}$ of 
Table 10 Maternity and neonatal outcomes by highest Scottish Credit and Qualifications Framework (SCQF) qualification at school leaving

\begin{tabular}{|c|c|c|c|c|c|c|c|c|}
\hline & $\begin{array}{l}\text { Number } \\
\text { of events }\end{array}$ & $\begin{array}{c}\text { No passes } \\
\text { at level } 3 \text { or } \\
\text { better }\end{array}$ & $\begin{array}{l}\text { SCQF } \\
\text { level } 3\end{array}$ & $\begin{array}{l}\text { SCQF } \\
\text { level } 4\end{array}$ & $\begin{array}{l}\text { SCQF } \\
\text { level } 5\end{array}$ & $\begin{array}{l}\text { SCQF } \\
\text { level } 6\end{array}$ & $\begin{array}{l}\text { SCQF } \\
\text { Level } 7\end{array}$ & Total \\
\hline $\begin{array}{l}\text { Total pregnancy rate } \\
\text { postschool leaving } / 1000 \text { women } \ddagger \S\end{array}$ & $28357^{\star \star}$ & 440 & 465 & 406 & 266 & 112 & 42 & 203 \\
\hline $\begin{array}{l}\text { Incident pregnancy rate post } \\
\text { school leaving/1000 women } \$ \S\end{array}$ & $21493^{\star *}$ & 300 & 334 & 307 & 211 & 95 & 37 & 158 \\
\hline $\begin{array}{l}\text { Live birth rate postschool leaving/1000 } \\
\text { women }\end{array}$ & $15821^{\star *}$ & 320 & 342 & 260 & 146 & 44 & 9 & 113 \\
\hline Medical abortion rate/1000 women§ & $11559^{\star *}$ & 101 & 102 & 131 & 111 & 65 & 31 & 83 \\
\hline $\begin{array}{l}\text { Stillbirth rate post } \\
\text { school leaving/1000 total births }\end{array}$ & 85 & $6+\dagger$ & NAt† & 6 & 4 & 5 & 0 & 5 \\
\hline $\begin{array}{l}\text { Perinatal death rate } \\
\text { postschool leaving/ } 1000 \text { total births } \neq \ddagger\end{array}$ & 109 & 8 & NA§§ & 8 & 6 & 5 & 0 & 7 \\
\hline $\begin{array}{l}\text { Neonatal death rate } \\
\text { postschool leaving/1000 live births } \| \text { १ }\end{array}$ & $30^{\star \star \star}$ & NA††† & NA††† & NA†† & NA††† & NA††† & NA††† & 2 \\
\hline $\begin{array}{l}\text { Multiple birth rate } \\
\text { postschool leaving/1000 maternities } \ddagger \ddagger \ddagger\end{array}$ & 103 & $6+\dagger$ & $\mathrm{NA}+\dagger$ & 7 & 7 & 6 & NA§§§ & 7 \\
\hline $\begin{array}{l}\text { Low birth weight incidence rate/100 live } \\
\text { births }\end{array}$ & $1081^{\star \star}$ & 8 & 11 & 7 & 6 & 5 & 5 & 7 \\
\hline $\begin{array}{l}\text { Mean age at first pregnancy (with abortive } \\
\text { or birth outcome) } 9\end{array}$ & $N A^{* \star}$ & 18 & 18 & 18 & 18 & 19 & 19 & 18 \\
\hline
\end{tabular}

Univariate Poisson regression was used to test for trend in each of the health outcomes by attainment.

${ }^{*} \mathrm{p}_{\text {trend }}<0.05$

${ }^{* *} p_{\text {trend }}<0.001$

†Incident pregnancy rate is defined as (\# of women whose first pregnancy was after school leaving)/(total \# of women with no history of pregnancy prior to school leaving). Unless stated, all other rates are based on all female cohort members and an individual may contribute more than one event.

$\ddagger$ Total and incident pregnancy rates include live births, stillbirths and spontaneous or medical abortion.

§Information on medical abortion comes from general acute inpatient and day case admissions (SMR01) scheme.

IIndividuals with any known history of pregnancy prior to school leaving have been excluded.

††Categories for no passes at SCQF 3 or better and SCQF 3 have been merged as $n<10$ in both. Results are presented under no passes at SCQF or better.

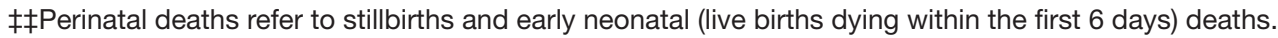

$\S \S$ Merged with no passes at SCQF 3 or better as $n<10$

११Neonatal deaths refer to early neonatal (live births dying within the first 6 days) and late neonatal (live births dying on or after the 7th completed day, but before the 28th day) deaths.

${ }^{\star \star \star} A$ test for trend across SCQF levels has not been performed due to small numbers.

$\dagger \dagger \dagger$ Numbers of events were too small to present rates by SCQF level. There were 30 neonatal deaths giving a rate of 2 per 1000 live births. $\ddagger \ddagger \ddagger$ Maternities refers to live births and stillbirths.

$\S \S \S$ Merged with no passes at SCQF 6 or better as $\mathrm{n}<10$.

NA, not applicable; SMR, Scottish Morbidity Record.

all Scottish school pupils attend privately funded schools, pupil numbers are not evenly distributed across Scotland, with numbers of private school pupils accounting for a greater proportion of all school pupils in some local authority council areas than others. ${ }^{56}$ There are data quality issues regarding the Attendance and Absence Survey. Variations in recording of certain absence reasons, particularly for sickness and truancy, over time and between local authorities means care should be taken when making year to year or local and national-level comparisons. ${ }^{57}$ However, overall attendance and absence rates are not affected. $^{57}$

Information on early life factors is missing for young people born out of Scotland as this information is extracted from birth and maternity records. Childhood mental and physical health problems may be underestimated for such individuals since acute and psychiatric hospital records, which are used to create measures of childhood health, are only available after entry to Scotland. There may also be misestimation of PYAR for rate 
calculations: overestimation for unknown international emigrants who are still assumed to be present in the cohort; and underestimation for individuals who have been incorrectly assumed to have migrated to elsewhere in the UK and have been removed from the cohort. Lastly, medical abortions carried out in private clinics were not included in rate calculations. However, the risk of underestimation is small as less than $1 \%$ of medical abortions in Scotland are performed outwith NHS premises. ${ }^{58}$

\section{COLLABORATION}

This study has demonstrated that education and health data for school leavers in Scotland can be linked to provide access to a large, representative cohort for studying educational variations in health outcomes in young adulthood. Researchers can apply for access to education and health data by making an application to the data controllers. School education data are held by the Education Analytical Services Division of the Scottish Government, http:/ / www.gov.scot/Topics/Statistics/Browse/School-Education/DataAccess and any queries should be directed to ASUSchools.Data.Access@gov.scot. Health data are held by National Services Scotland http://www.isdscotland. org/Products-and-Services/EDRIS/, queries can be made by email to nss.edris@nhs.net. Researchers will need to seek the relevant permissions to link the data.

Acknowledgements The authors thank Ailie Clarkson (ScotXed), John Nolan (NHS NSS, ISD) and Noel Thompson (SQA) for their continued assistance with data queries. The authors also thank Dr Rachael Wood (NHS NSS, ISD) and Prof Jill Pell (University of Glasgow) for giving them permission to use and adapt the diagram of data flows for linking education and health data (figure 2) for their study.

Contributors All authors devised the study and were involved in sourcing data. CHS cleaned, merged and analysed the data, and wrote the first draft of the report. All authors critically revised the report and approved the final version.

Funding Medical Research Council (MC_UU_12017/13) and the Scottish Government Chief Scientist Office (SPHSU13).

Competing interests None declared.

Provenance and peer review Not commissioned; externally peer reviewed.

Data sharing statement Researchers can apply for access to education data via the Education Analytical Services Division of the Scottish Government. http:// www.gov.scot/Topics/Statistics/Browse/School-Education/DataAccess and any queries should be directed to ASUSchools.Data.Access@gov.scot and health data via National Services Scotland http://www.isdscotland.org/Products-and-Services/ EDRIS/, directing any queries to nss.edris@nhs.net.

Open Access This is an Open Access article distributed in accordance with the terms of the Creative Commons Attribution (CC BY 4.0) license, which permits others to distribute, remix, adapt and build upon this work, for commercial use, provided the original work is properly cited. See: http://creativecommons.org/ licenses/by/4.0/

(C) Article author(s) (or their employer(s) unless otherwise stated in the text of the article) 2017. All rights reserved. No commercial use is permitted unless otherwise expressly granted.

\section{REFERENCES}

1. Mackenbach JP, Bakker MJ. Tackling socioeconomic inequalities in health: analysis of European experiences. Lancet 2003;362:1409-14.

2. World Health Organization. Targets for health for all. Copenhagen: WHO Regional Office for Europe, 1986.
3. World Health Organization. Health 21: an introduction to the health for all policy framework for the WHO European Region. Copenhagen: WHO Regional Office for Europe, 1998.

4. Prinja S, Kumar R. Reducing health inequities in a generation: a dream or reality? Bull World Health Organ 2009;87:84.

5. Adler NE, Boyce WT, Chesney MA, et al. Socioeconomic inequalities in health: no easy solution. JAMA 1993;269:3140-5.

6. Adler NE, Newman K. Socioeconomic disparities in health: pathways and policies. Health Aff 2002;21:60-76.

7. Daly MC, Duncan GJ, McDonough P, et al. Optimal Indicators of Socioeconomic Status for Health Research. Am J Public Health 2002:92:1151-7.

8. Cutler DM, Lleras-Muney A, Vogl T. Socioeconomic status and health: dimensions and mechanisms. Cambridge, MA: National Bureau of Economic Research, 2008. Working Paper Series No. 14333.

9. Galobardes B, Lynch J, Smith GD. Measuring socioeconomic position in health research. Br Med Bull 2007;81-82:21-37.

10. Currie CE, Elton RA, Todd J, et al. Indicators of socioeconomic status for adolescents: the WHO health Behaviour in School-aged Children survey. Health Educ Res 1997;12:385-97.

11. Davey Smith G, Hart C, Hole D, et al. Education and occupational social class: which is the more important indicator of mortality risk? $\mathrm{J}$ Epidemiol Community Health 1998;52:153-60.

12. West P. Inequalities? Social class differentials in health in British youth. Soc Sci Med 1988;27:291-6.

13. West $P$, Sweeting $H$. Health inequalities: what's going on in youth? Health Educ 1996;5:14-20.

14. Hanson MD, Chen E. Socioeconomic Status and Health Behaviors in Adolescence: a review of the literature. J Behav Med 2007:30:263-85.

15. Galobardes B, Shaw M, Lawlor DA, et al. Indicators of socioeconomic position (part 1). J Epidemiol Community Health 2006;60:7-12.

16. Christenson BA, Johnson NE. Educational inequality in adult mortality: an assessment with death certificate data from Michigan. Demography 1995;32:215-29.

17. Elo IT, Preston SH. Educational differentials in mortality: United States, 1979-85. Soc Sci Med 1996;42:47-57.

18. von dem Knesebeck O, Verde PE, Dragano N. Education and health in 22 European countries. Soc Sci Med 2006;63:1344-51.

19. Ross CE, Wu C-ling. The links between education and health. Am Sociol Rev 1995;60:719-45.

20. Brännlund A, Hammarström A, Strandh M, Education SM. Education and health-behaviour among men and women in Sweden: a 27 -year prospective cohort study. Scand J Public Health 2013;41:284-92.

21. Scottish Government. Better health, better care: action plan. Edinburgh: The Scottish Government, 2007.

22. Scottish Exchange of Education Data (ScotXed) Unit. School leavers (Christmas) Survey background. http://www.gov.scot/Topics/ Statistics/ScotXed/SchoolEducation/SchoolLeaversChristmas (accessed 15 Sep 2016).

23. Scottish Exchange of Education Data (ScotXed) Unit. School leavers (Summer) Survey background. http://www.gov.scot/Topics/Statistics/ ScotXed/SchoolEducation/SchoolLeaversSummer (accessed 15 Sep 2016).

24. Scottish Government. What can I do at my age. 2009 http://www. scotland.gov.uk/Publications/2009/04/02155040/12014).

25. Administrative Data Liaison Service. Dataset summary: pupils in Scotland census. $2014 \mathrm{http}: / /$ www.adls.ac.uk/the-scottishgovernment/pupils-in-scotland-census/?detail2014).

26. Scottish Exchange of Education Data (ScotXed) Unit. Attendance, absence and exclusions survey background. http:// www.gov.scot/Topics/Statistics/ScotXed/SchoolEducation/ AttendanceAbsenceExclusions (accessed 15 Sep 2016).

27. Scottish Government. Scottish index of multiple deprivation 2012: a national statistics publication for Scotland. $2012 \mathrm{http}: / /$ 22fa0f74501b902c9f11-8b3fbddfa1e1fab453a8e75cb14f3396.r26. cf3.rackcdn.com/simd_448749 v7 20121217.pdf (accessed 22 Jan 2016).

28. Scottish Exchange of Education Data (ScotXed) Unit. The Scottish Candidate Number.

29. Scottish Exchange of Education Data (ScotXed) Unit. School/Pupil census survey background. http://www.gov.scot/Topics/Statistics/ ScotXed/SchoolEducation/SchoolPupilCensus (accessed $15 \mathrm{Sep}$ 2016).

30. Skills Development Scotland. School Leaver destinations statistics. https://www.skillsdevelopmentscotland.co.uk/publications-statistics/ statistics/school-leaver-destinations/?page $=1 \&$ statisticCategoryld= 8\&order=date-desc (accessed 15 Sep 2016). 
31. Information Services Division Scotland. eDRIS frequently asked questions: can you explain the data linkage process? http://www. isdscotland.org/Products-and-Services/EDRIS/FAQ-eDRIS/index. asp?Co=Y\#e1 (accessed 30 Jan 2017).

32. Fleming M, Kirby B, Penny KI. Record linkage in Scotland and its applications to health research. J Clin Nurs 2012;21(19-20):2711-21.

33. Gray L, Batty GD, Craig P, et al. Cohort profile: the scottish health surveys cohort: linkage of study participants to routinely collected records for mortality, hospital discharge, Cancer and offspring birth characteristics in three nationwide studies. Int $\mathrm{J}$ Epidemiol 2010;39:345-50.

34. Information Services Division Scotland. Data quality assurance: assessment of SMR01 data Scotland 2014-2015. Scotland: Information Services Division Scotland, 2015.

35. Craig P. The Scottish Health Survey-Scottish Morbidity Record Linked Datasets: introduction to a new resource. www.ccsr.ac.uk/ esds/events/2008-07-08/petercraig.ppt2014

36. Information Services Division Scotland. ISD Scotland data dictionary chi number. http://www.ndc.scot.nhs.uk/Dictionary-A-Z/Definitions/ index.asp?Search=C\&ID=128\&Title=CHI\%20Number11 (accessed 11 Jan 2017).

37. Scottish Informatics Programme. Background: Scotland's unique resources. http://www.scot-ship.ac.uk/overview.html (accessed 11 Jan 2017).

38. Gray R, Bonellie SR, Chalmers J, et al. Social inequalities in preterm birth in Scotland 1980-2003: findings from an area-based measure of deprivation. BJOG 2008;115:82-90.

39. Scottish Government. Guiding principles for data linkage. Scotland: Scottish Government, 2012.

40. NHS National Services Scotland. Privacy advisory committee. https://nhsnss.org/how-nss-works/policies-and-statements/privacyadvisory-committee/ (accessed 20 Jan 2017).

41. Information and Sevices Division Scotland. SMR completeness from 2009. Scotland: Information and Sevices Division Scotland, 2010.

42. Scottish Qualifications Authority. SCQF interactive ready reckoner. 2016 http://www.sqa.org.uk/files_ccc/readyreckoner.html (accessed 6 Sep 2016).

43. Stewart $\mathrm{C}$, Leyland $\mathrm{AH}$. Education as a mediator of the relationship between low birthweight and attempted and completed suicide in young adults in Scotland, 2007-2012. Eur J Public Health 2014;24(suppl_2):cku163-044.

44. Stewart $\mathrm{C}$, Leyland $\mathrm{AH}$. Educational inequalities in offspring birthweight: cohort study of young mothers in Scotland, 2007-12. Eur J Public Health 2015;25(suppl_3):ckv170.053.
45. NHS Scotland. Spire: scottish primary care information resource. 2016 http://www.spire.scot.nhs.uk/ (accessed 12 Sep 2016).

46. Stewart $\mathrm{CH}$. Multilevel modelling of event history data: comparing methods appropriate for large datasets. Scotland: University of Glasgow and MRC/CSO Social \& Public Health Sciences Unit, 2010.

47. World Health Organisation. Integrating mental health into primary care: a global perspective. Switzerland: World Health Organisation, 2008.

48. Scottish Government. Mental health strategy for Scotland 20122015. Scotland: Scottish Government, 2012.

49. Scottish Government. SQA attainment and school Leaver qualifications in Scotland: 2008-09 - Annex A: unified points score scale. 2010 http://www.gov.scot/Publications/2010/03/22111037/4 (accessed 2 Feb 2017).

50. Raab G. Technical working paper 6: education data available within

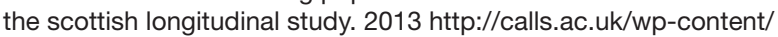
uploads/LSCS-WP-6.pdf2014.

51. Wood R, Clark D, King A, et al. Novel cross-sectoral linkage of routine health and education data at an all-Scotland level: a feasibility study. The Lancet 2013;382(suppl 3):S10.

52. Mackay DF, Wood R, King A, et al. Educational outcomes following breech delivery: a record-linkage study of 456947 children. Int J Epidemiol 2015;44:209-17.

53. Tweed EJ, Mackay DF, Nelson SM, et al. Five-minute Apgar score and educational outcomes: retrospective cohort study of 751,369 children. Arch Dis Child Fetal Neonatal Ed 2016;101:F121-F126.

54. Gayle V, Berridge D, Davies R. Young People's Entry into Higher Education: Quantifying influential factors. Oxf Rev Educ 2002;28:5-20.

55. Scottish Government. High Level Summary of Statistics data for School Education trends. In: High level summary of statistics trends Chart data, ed., 2015, 2015. Ind Schools - Data.

56. Scottish Council of Independent Schools. Pupil number comparisons by local authority area 2011/12. 2012 http://www.scis.org.uk/assets/ Uploads/Facts-and-Statistics/2011-Local-Authority-comparisons-byregion.pdf (accessed Sep 2015).

57. Scottish Government. Summary statistics for schools in Scotland, no. 2 : 2011 edition. Scotland: Scottish Government, 2012.

58. Bhattacharya S, Lowit A, Bhattacharya S, et al. Reproductive outcomes following induced abortion: a national register-based cohort study in Scotland. BMJ Open 2012;2:e000911. 